\title{
Monitoring cotton bollworms through synthetic sex pheromone traps
}

\author{
Ghulam Nabi Sehto ${ }^{1}$, Imran Ali Rajput ${ }^{2 *}$, Agha Mushtaque Ahmed ${ }^{3}$, \\ Meer Muhammad Kolachi ${ }^{1}$, Attaullah Khan Pathan ${ }^{4}$, Muhammad \\ Siddique Depar ${ }^{2}$, Rauf Ahmed Khan Laghari ${ }^{1}$ and Bhugro Mal ${ }^{4}$ \\ 1. CABI- Central \& West Asia International (CWA) Rawalpindi-Pakistan \\ 2. PARC-Arid Zone Research Institute, Umerkot, Sindh-Pakistan \\ 3. Department of Entomology, Sindh Agriculture University, Tandojam-Pakistan \\ 4. PARC-Southern Zone Agricultural Research Centre, Karachi, Sindh-Pakistan \\ *Corresponding author's email: ranaimran234@gmail.com \\ Citation \\ Ghulam Nabi Sehto, Imran Ali Rajput, Agha Mushtaque Ahmed, Meer Muhammad Kolachi, Attaullah Khan \\ Pathan, Muhammad Siddique Depar, Rauf Ahmed Khan Laghari and Bhugro Mal. Pure and Applied Biology. \\ Vol. 9, Issue 3, pp2007-2013. http://dx.doi.org/10.19045/bspab.2020.90214
}

\begin{tabular}{llll}
\hline \hline Received: 05/03/2020 & Revised: 30/05/2020 & Accepted: 08/06/2020 & Online First: 16/06/2020 \\
\hline
\end{tabular}

\section{Abstract}

Bollworms are most serious pests of cotton crop which do not only cause losses by devouring foliage and fruiting bodies of cotton which results in low yield but also deteriorate its lint quality. Their management relies on application of pesticides but recent introduction of synthetic pheromones for mass trapping of their adult moths have given better solution for recording and monitoring their population. We used five different components of synthetic sex pheromone installed in funnel type traps (4 traps/per acre) at different localities of district Sanghar. The components were $(0 \mathrm{E}, 12 \mathrm{E})-10,12$ Hexadecadienal for Earias insulana (Boisduval), Z7, Z11-16AC (50), Z7, E11-16AC (50) Hexadecadienyle Acetate for Pectinophora gossypiella (Saunders), D, Z11-16AL (97), Z9-16 AL (3) Hexedecenal for Helicoverpa armeigera (Hubner) and (Z, E)-9,11- and (Z, E)-9, 12-tetradecadienyl acetate (Z9, E11-14: Ac; Z9, E12-14: Ac) for Spodoptera litura (Fabricius). All these bollworm species in different localities were successfully trapped with significant different population. A maximum population of $P$. gossypiella and $H$. armigera were at Tando Adam, E. insulana at Shadadpur and S. litura at Jam Nawaz Ali. P. gossypiella trapped maximal in the month of October, E. insulana in September, H. armigera in August and S. litura in November, respectively. Based on the results, it is recommended that these pheromone lures should be introduced at different timings and pest species according to their presence.

Keywords: Cotton; Bollworms; Population; Sex pheromone

\section{Introduction}

Cotton Gossypium hirsutum L. is one of the important cash crops grown in Pakistan. It contributes substantially $(1.4 \%)$ to the national economy and possess a primary source of livelihood for rural people [1]. During the current year 2018, cotton production was 9.86 million bales, with a decrease of 17.5 percent over the production of 2017 (11.946 million bales).
This below expectation performance of the cotton crop was largely due to reduction in the cultivated area on account of less economic incentive given to the farmers [2]. There are number of factors responsible for lower cotton yield but insects are ranked at the top, which do not only deteriorate the quality of cotton but also reduce the yields [3]. Cotton crop is mostly attacked by the insect pests from seedling to 
harvesting but the maximum losses $(30-40 \%)$ are recorded by bollworms [4]. In bollworms, army worm Spotdoptera litura (Fabricius), spotted bollworm Earias insulana (Fabricius), american bollworm Helicoverpa armigera (Hubner) and pink bollworm Pectinophora gossypiella (Saunders) are the major pests of cotton crop [5]. Among these bollworms, $P$. gossypiella is the most serious pest because it damages the reproductive part of crop during immature stage (larvae), remains inside bolls and very difficult to control with by insecticides. The pest is widely distributed all over the world particularly in India and Pakistan. The other two species of bollworms tend to cause more conspicuous damage particularly to the newly developing fruiting bodies and the terminal shoots. Meanwhile, these bollworms badly affect the quantity and quality of the lint. Control of these pest species with conventional insecticides is very difficult due to high cost and inaccessibility [6].

The use of sex pheromone lures for insect monitoring and reducing their population by adult moth trapping nowadays is the common practice by various cotton research institutes of Pakistan. Some progressive growers are also well familiar with application of different pheromones in cotton crop, as these are inexpensive and eco-friend strategy in integrated pest management tools [7]. Since few years, it has been well documented that synthetic pheromones are better to monitor and control the cotton bollworms population as compared to other control measures [8]. In Sindh province, few studies regarding use of pheromone have been previously conducted [9], but there is still lack of studies conducted in district Sanghar, which is to be considered as hub of cotton growing and processing area of Sindh province. Therefore, the aim of present experiment was designed to observe the population of cotton bollworms through synthetic sex pheromone traps in the various locations of district Sanghar, Sindh, Pakistan.

\section{Materials and methods}

The study was conducted at four localities of district Sanghar i.e., Tando Adam, Shahdadpur, Jam Nawaz Ali and Sinjhoro. In each locality, 4 traps/ acre with four replications were selected for different bollworm species. There were no application of pesticide was applied throughout the study. The synthetic sex pheromone lures were (0E, 12E)-10, 12 Hexadecadienal for E. insulana, Z7 Z11 16AC (50), Z7 E11 - 16AC (50) Hexadecadienyle Acetate for $P$. gossypiella, D. Z11-16AL (97), Z9 -16 AL (3) Hexedecenal for $H$. armeigera and (Z,E)-9,11- and (Z,E)-9,12-tetradecadienyl acetate (Z9, E11-14: Ac; Z9, E12-14: Ac) for $S$. litura. These lures were installed in funnel type traps and fixed at 1 foot above the crop level in 7-shaped structure wooden frame (Fig. 1).We followed the procedure as described previously [10].

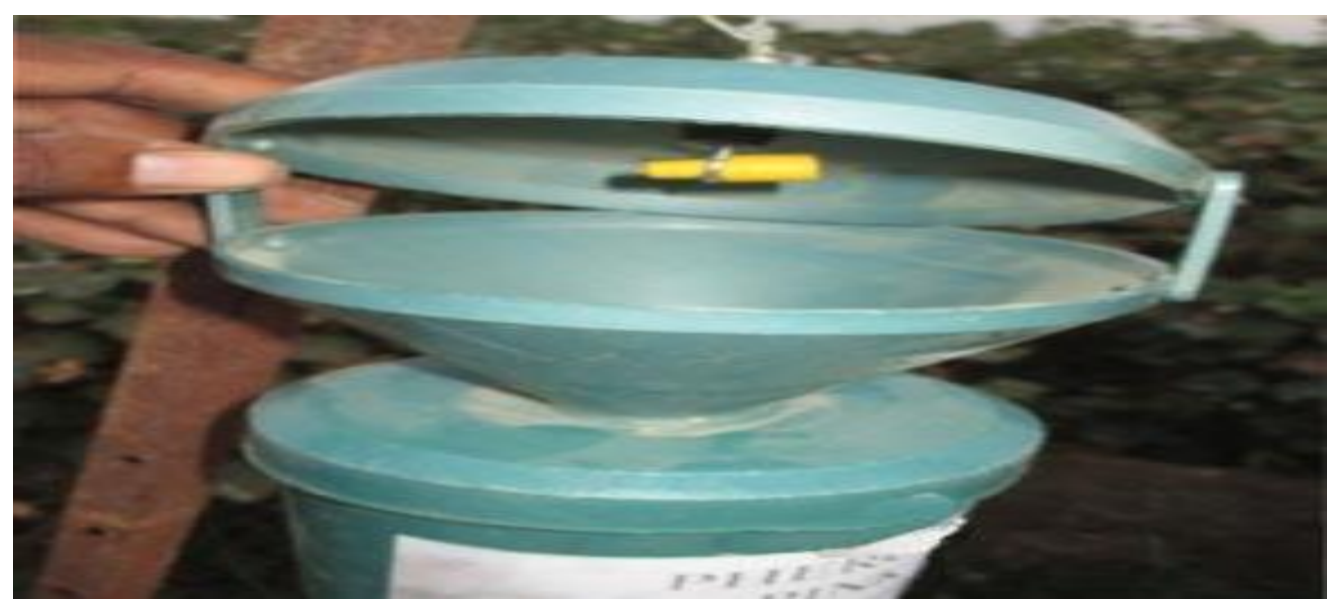

Figure 1. Funnel type pheromone trap 
The synthetic sex pheromone traps for each species were replaced after every 15 days and data were recorded fortnightly. Trapped adults were brought and counted in separate Petri dishes $(11 \times 15 \mathrm{~mm})$.

\section{Data analysis}

The experiment was laid out in Randomized Complete Block Design (RCBD) with four treatments and four replications. The data were subjected to analysis by using ANOVA statistical test and the means were separated by using Fisher's Least Significant Difference (LSD) at 5\% level. All the statistical tests were done by using SAS (Ver. 9.2).

\section{Results and discussion}

The population of $P$. gossypiella in different localities were significantly different $(\mathrm{DF}=3 ; \mathrm{F}=11.76 ; P<0.05)$. The highest mean population was $8.49 \pm 0.26$ at Tando Adam followed by $8.26 \pm 0.22$ at Shahdadpur with non-significant difference and the lowest was $4.87 \pm 0.19$ at Sinjhoro followed by $5.17 \pm 0.14$ at Jam Nawaz Ali also with non-significant difference. However, the collective weekly population of $P$. gossypiella at all localities was highest $(31.65 \pm 3.1)$ in the second week of October (Table 1).

The population of $H$. armigera were nonsignificantly different at different localities $(\mathrm{DF}=3 ; \mathrm{F}=5.09 ; P>0.05)$. The maximum population of $H$. armigera was $0.91 \pm 0.09$ at Tando Adam followed by $0.82 \pm 0.05$ at Sinjhoro, $0.72 \pm 0.03$ at Shahdadpur and minimum $0.68 \pm 0.11$ at Jam Nawaz Ali. The collective weekly population of $H$. armigera at all localities was highest $(6.42 \pm 0.23)$ in the last week of August (Table 2).

The population of E. insulana were nonsignificantly differentat different localities $(\mathrm{DF}=3 ; \mathrm{F}=5.09 ; P>0.05)$. The maximum population of $E$. insulana was $1.77 \pm 0.15$ at Shahdadpur followed by $1.70 \pm 0.13$ at Jam Nawaz Ali, $1.62 \pm 0.13$ at Tando Adam, and $1.42 \pm 0.11$ at Sinjhoro. The collective weekly population of $E$. insulana at all localities was highest $(9.37 \pm 1.09)$ in the third week of September as in (Table 3).
The population of $S$. litura in different localities were non-significantly different $(\mathrm{DF}=3 ; \mathrm{F}=6.09 ; P>0.05)$. The highest mean population was $2.46 \pm 0.89$ at Jam Nawaz Ali followed by $2.11 \pm 0.73$ at Tando Adam, 2.06 \pm 0.31 at Sinjhoro and $1.98 \pm 0.21$ at Shahdadpur. However, the collective weekly population of $S$. litura at all localities was highest $(10.24 \pm 1.31)$ in the first week of November (Table 4).

The results of sex pheromone traps in (Fig. $2 \&$ Table 5), showed that the adult population of bollworms was varied at the different localities. The results showed that the maximum number of adults were collected from Tando Adam, followed by Shahdadpur, Jam Nawaz Ali, and Sinjhoro. Comparison between adult species and the maximum number of $P$. gossypiella adults were trapped as compared to $S$. litura, E. insulana, and $H$. armigera.

The population of $P$. gossypiella was correlated with abiotic factors, that it showed positive correlation $(\mathrm{r}=0.812$, $\mathrm{p}<0.05)$ with highly significant difference with temperature and relative humidity was significantly different $(0.69, \mathrm{p}<0.05)$ and further showed non-significant different $(0.52, \mathrm{p}>0.05)$ with dates. The population of E. insulana was correlated with abiotic factors, that it showed positive correlation $(\mathrm{r}=0.50, \mathrm{p}<0.05)$ with lowest significant difference with temperature and relative humidity was lowest significantly different $(0.49, \mathrm{p}<0.05)$ and further showed nonsignificant different $(0.49, \mathrm{p}>0.05)$ with dates. The population of $S$. litura was correlated with abiotic factors, that it showed positive correlation $(\mathrm{r}=0.63$, $\mathrm{p}<0.05)$ with lowest significant difference with temperature and relative humidity was lowest significantly different $(0.55, \mathrm{p}<0.05)$ and further showed non-significant different $(0.51, \mathrm{p}>0.05)$ with dates. The population of $H$. armigera was correlated with abiotic factors, that it showed positive correlation $(r=0.51, p<0.05)$ with lowest 
significant difference with temperature and relative humidity was lowest significantly different $(0.48, \mathrm{p}<0.05)$ and further showed non-significant different $(0.50, \mathrm{p}>0.05)$ with dates.

Bollworms, H. armigera, P. gossypiella, E. insulana and $S$. litura are major pests of cotton [11]. Present results are in agreement with [12-14] who indicated that sex pheromones proved more effective for monitoring the adult moth of bollworms. $P$. gossypiella was very attractant to sex pheromones as compared to other bollworms [15, 16]. Present results supported the findings of [17-19] who also reported that maximum population of Pink bollworm was observed during October. [20] recorded highest population of $E$. insulana in the month of September, whereas large numbers of $H$. armigera were recorded during the month of August to September. Some other researchers observed with little difference and reported; [21] used sex pheromones for control of bollworm in Multan (Pakistan), according to him maximum population of adult moths were recorded in the month of September and October and minimum in the month of June, $[22,23]$ have also presented similar results. [24] Also had same observation for bollworm species in Sindh.

Table 1. Weekly adult population (Mean \pm S.E) of $\boldsymbol{P}$. gossypiella at different localities of district Sanghar (2018)

\begin{tabular}{|c|c|c|c|c|c|}
\hline \multirow{2}{*}{ Dates } & \multicolumn{5}{|c|}{ Adult population } \\
\cline { 2 - 5 } & \multicolumn{4}{|c|}{ gossypiella } & \multirow{2}{*}{ Grand total } \\
\cline { 2 - 5 } & Shahdadpur & Tando Adam & Sinjhoro & $\begin{array}{c}\text { Jam Nawaz } \\
\text { Ali }\end{array}$ & \\
\hline $14 / 08 / 18$ & 8.66 & 8.00 & 2.33 & 4.33 & $23.32 \pm 0.9 \mathrm{bc}$ \\
\hline $21 / 08 / 18$ & 9.21 & 8.33 & 3.66 & 4.09 & $25.65 \pm 1.2 \mathrm{~b}$ \\
\hline $28 / 08 / 18$ & 7.61 & 9.66 & 4.66 & 4.32 & $25.98 \pm 1.1 \mathrm{~b}$ \\
\hline $04 / 09 / 18$ & 9.09 & 9.33 & 4.33 & 4.09 & $26.66 \pm 0.4 \mathrm{~b}$ \\
\hline $11 / 09 / 18$ & 8.45 & 8.66 & 4.66 & 3.66 & $25.64 \pm 1.1 \mathrm{~b}$ \\
\hline $18 / 09 / 18$ & 8.34 & 8.66 & 6.78 & 5.33 & $29.1 \pm 2.9 \mathrm{a}$ \\
\hline $25 / 09 / 18$ & 8.66 & 9.09 & 4.33 & 5.66 & $27.65 \pm 1.8 \mathrm{~b}$ \\
\hline $02 / 10 / 18$ & 8.56 & 9.01 & 4.33 & 4.66 & $26.65 \pm 0.5 \mathrm{~b}$ \\
\hline $09 / 10 / 18$ & 8.38 & 10.01 & 4.66 & 7.66 & $31.65 \pm 3.1 \mathrm{a}$ \\
\hline $16 / 10 / 18$ & 9.21 & 9.01 & 5.34 & 6.57 & $29.57 \pm 2.8 \mathrm{a}$ \\
\hline $23 / 10 / 18$ & 6.68 & 8.21 & 5.66 & 6.32 & $26.64 \pm 0.6 \mathrm{~b}$ \\
\hline $01 / 11 / 18$ & 6.66 & 8.33 & 6.66 & 8.66 & $30.31 \pm 2.8 \mathrm{a}$ \\
\hline $06 / 11 / 18$ & 8.06 & 10.66 & 6.66 & 6.33 & $30.65 \pm 2.9 \mathrm{a}$ \\
\hline $13 / 11 / 18$ & 7.33 & 6.33 & 4.66 & 3.00 & $21.32 \pm 0.6 \mathrm{c}$ \\
\hline $20 / 11 / 18$ & 8.66 & 4.33 & 4.61 & 3.33 & $20.93 \pm 0.4 \mathrm{~cd}$ \\
\hline & $8.26 \pm 0.22 \mathrm{a}$ & $8.49 \pm 0.26 \mathrm{a}$ & $4.87 \pm 0.19 \mathrm{~b}$ & $5.17 \pm 0.14 \mathrm{~b}$ & \\
\hline
\end{tabular}

Table 2. Weekly adult population (Mean \pm S.E) of $H$. armigera attracted to sex pheromone traps

\begin{tabular}{|c|c|c|c|c|c|}
\hline \multirow{3}{*}{ Dates } & \multicolumn{5}{|c|}{ Adult population } \\
\hline & \multicolumn{4}{|c|}{ H. armigera } & \multirow[b]{2}{*}{ Grand total } \\
\hline & Shahdadpur & Tando Adam & Sinjhoro & $\begin{array}{c}\text { Jam Nawaz } \\
\text { Ali }\end{array}$ & \\
\hline $14 / 08 / 18$ & 0.96 & 0.02 & 1.11 & 1.15 & $3.24 \pm 0.09 b c$ \\
\hline $21 / 08 / 18$ & 0.99 & 1.05 & 1.33 & 1.35 & $4.72 \pm 0.12 b$ \\
\hline $28 / 08 / 18$ & 1.37 & 1.06 & 1.9 & 2.09 & $6.42 \pm 0.23 a$ \\
\hline $04 / 09 / 18$ & 1.66 & 0.06 & 0.93 & 1.93 & $4.58 \pm 0.03 b$ \\
\hline $11 / 09 / 18$ & 1.08 & 1.54 & 0.26 & 0.26 & $3.14 \pm 0.54 b c$ \\
\hline
\end{tabular}




\begin{tabular}{|c|c|c|c|c|c|}
\hline $18 / 09 / 18$ & 0.38 & 1.63 & 1.55 & 0.55 & $4.11 \pm 0.32 \mathrm{~b}$ \\
\hline $25 / 09 / 18$ & 0.66 & 1.00 & 0.69 & 0.69 & $3.04 \pm 0.07 \mathrm{bc}$ \\
\hline $02 / 10 / 18$ & 0.22 & 1.29 & 0.81 & 0.11 & $2.43 \pm 0.12 \mathrm{c}$ \\
\hline $09 / 10 / 18$ & 0.61 & 0.98 & 0.51 & 0.11 & $2.21 \pm 0.09 \mathrm{c}$ \\
\hline $16 / 10 / 18$ & 0.91 & 1.02 & 0.85 & 0.15 & $2.93 \pm 0.13 \mathrm{c}$ \\
\hline $23 / 10 / 18$ & 0.24 & 1.02 & 0.11 & 0.13 & $1.5 \pm 0.05 \mathrm{c}$ \\
\hline $01 / 11 / 18$ & 0.35 & 1.05 & 0.33 & 0.17 & $1.9 \pm 0.04 \mathrm{c}$ \\
\hline $06 / 11 / 18$ & 0.21 & 0.13 & 0.23 & 0.18 & $0.75 \pm 0.05 \mathrm{~d}$ \\
\hline $13 / 11 / 18$ & 0.96 & 0.20 & 1.11 & 0.90 & $2.24 \pm 0.25 \mathrm{c}$ \\
\hline $20 / 11 / 18$ & 0.99 & 0.50 & 0.33 & 1.35 & $1.72 \pm 0.11 \mathrm{c}$ \\
\hline & $0.72 \pm 0.03 \mathrm{a}$ & $0.91 \pm 0.09 \mathrm{a}$ & $0.82 \pm 0.05 \mathrm{a}$ & $0.68 \pm 0.01 \mathrm{a}$ & \\
\hline
\end{tabular}

Table 3. Weekly adult population $($ Mean \pm S.E) of E. insulana attracted to sex pheromone traps

\begin{tabular}{|c|c|c|c|c|c|}
\hline \multirow{2}{*}{ Dates } & \multicolumn{5}{|c|}{ Adult population } \\
\cline { 2 - 5 } & \multicolumn{4}{|c|}{ E. insulana } & \multirow{2}{*}{ Grand total } \\
\cline { 2 - 5 } & Shahdadpur & Tando Adam & Sinjhoro & Jam Nawaz Ali & \\
\hline $14 / 08 / 18$ & 1.16 & 1.12 & 0.16 & 1.05 & $3.49 \pm 0.31 \mathrm{~d}$ \\
\hline $21 / 08 / 18$ & 1.19 & 1.25 & 1.36 & 1.31 & $5.11 \pm 1.12 \mathrm{c}$ \\
\hline $28 / 08 / 18$ & 1.17 & 1.16 & 1.09 & 1.01 & $4.43 \pm 0.98 \mathrm{~cd}$ \\
\hline $04 / 09 / 18$ & 1.26 & 1.34 & 1.43 & 1.13 & $5.16 \pm 1.10 \mathrm{c}$ \\
\hline $11 / 09 / 18$ & 3.18 & 2.21 & 1.16 & 2.26 & $8.81 \pm 2.10 \mathrm{a}$ \\
\hline $18 / 09 / 18$ & 3.38 & 2.33 & 1.51 & 2.15 & $9.37 \pm 1.09 \mathrm{a}$ \\
\hline $25 / 09 / 18$ & 2.66 & 2.04 & 2.19 & 2.16 & $9.05 \pm 1.23 \mathrm{a}$ \\
\hline $02 / 10 / 18$ & 2.12 & 2.89 & 1.51 & 2.31 & $8.83 \pm 1.21 \mathrm{a}$ \\
\hline $09 / 10 / 18$ & 1.61 & 2.18 & 2.13 & 2.04 & $7.96 \pm 1.08 \mathrm{~b}$ \\
\hline $16 / 10 / 18$ & 1.91 & 2.02 & 2.18 & 2.13 & $8.24 \pm 0.99 \mathrm{a}$ \\
\hline $23 / 10 / 18$ & 1.43 & 1.32 & 1.21 & 2.15 & $6.11 \pm 0.98 \mathrm{~b}$ \\
\hline $01 / 11 / 18$ & 1.11 & 1.13 & 1.31 & 1.17 & $4.72 \pm 0.67 \mathrm{~cd}$ \\
\hline $06 / 11 / 18$ & 0.79 & 0.13 & 1.21 & 1.18 & $3.31 \pm 0.21 \mathrm{~d}$ \\
\hline $13 / 11 / 18$ & 1.16 & 1.12 & 0.16 & 1.05 & $3.49 \pm 0.11 \mathrm{~d}$ \\
\hline $20 / 11 / 18$ & 0.90 & 1.00 & 0.36 & 1.31 & $2.11 \pm 0.21 \mathrm{~d}$ \\
\hline & $1.77 \pm 0.15 \mathrm{a}$ & $1.62 \pm 0.13 \mathrm{a}$ & $1.42 \pm 0.11 \mathrm{a}$ & $1.70 \pm 0.13 \mathrm{a}$ & \\
\hline
\end{tabular}

Table 4. Weekly adult population (Mean \pm S.E) of $S$. litura attracted to sex pheromone traps

\begin{tabular}{|c|c|c|c|c|c|}
\hline \multirow{2}{*}{ Dates } & \multicolumn{5}{|c|}{ Adult population } \\
\cline { 2 - 5 } & Shahdadpur & Tando Adam & Sinjhoro & $\begin{array}{c}\text { Jam Nawaz } \\
\text { Ali }\end{array}$ & $\begin{array}{c}\text { Grand } \\
\text { total }\end{array}$ \\
\hline $14 / 08 / 18$ & 2.14 & 2.12 & 2.14 & 2.15 & $8.55 \pm 1.21 \mathrm{~b}$ \\
\hline $21 / 08 / 18$ & 2.11 & 2.21 & 2.78 & 2.71 & $9.81 \pm 1.29 \mathrm{a}$ \\
\hline $28 / 08 / 18$ & 2.17 & 2.11 & 1.19 & 2.91 & $8.38 \pm 1.09 \mathrm{~b}$ \\
\hline $04 / 09 / 18$ & 2.26 & 3.14 & 1.13 & 2.73 & $9.26 \pm 1.09 \mathrm{a}$ \\
\hline $11 / 09 / 18$ & 1.18 & 2.21 & 2.16 & 1.16 & $6.71 \pm 0.13 \mathrm{c}$ \\
\hline $18 / 09 / 18$ & 1.18 & 1.13 & 2.51 & 1.75 & $6.57 \pm 0.05 \mathrm{c}$ \\
\hline $25 / 09 / 18$ & 1.36 & 1.45 & 2.89 & 3.06 & $8.76 \pm 0.95 \mathrm{~b}$ \\
\hline $02 / 10 / 18$ & 3.19 & 1.69 & 2.27 & 2.61 & $9.76 \pm 0.89 \mathrm{a}$ \\
\hline $09 / 10 / 18$ & 2.31 & 1.16 & 1.19 & 2.34 & $7.00 \pm 0.23 \mathrm{c}$ \\
\hline $16 / 10 / 18$ & 1.21 & 2.42 & 1.17 & 1.19 & $5.99 \pm 0.52 \mathrm{c}$ \\
\hline $23 / 10 / 18$ & 2.13 & 2.38 & 2.41 & 2.65 & $9.57 \pm 1.09 \mathrm{a}$ \\
\hline
\end{tabular}




\begin{tabular}{|c|c|c|c|c|c|}
\hline $01 / 11 / 18$ & 2.11 & 3.10 & 2.11 & 2.47 & $9.79 \pm 1.07 \mathrm{a}$ \\
\hline $06 / 11 / 18$ & 2.12 & 2.23 & 2.71 & 3.18 & $10.24 \pm 1.31 \mathrm{a}$ \\
\hline $13 / 11 / 18$ & 2.14 & 2.12 & 1.97 & 3.09 & $9.32 \pm 1.07 \mathrm{a}$ \\
\hline $20 / 11 / 18$ & 2.15 & 2.15 & 2.25 & 2.97 & $9.52 \pm 1.17 \mathrm{a}$ \\
\hline & $1.98 \pm 0.21 \mathrm{a}$ & $2.11 \pm 0.73 \mathrm{a}$ & $2.06 \pm 0.31 \mathrm{a}$ & $2.46 \pm 0.89 \mathrm{a}$ & \\
\hline
\end{tabular}

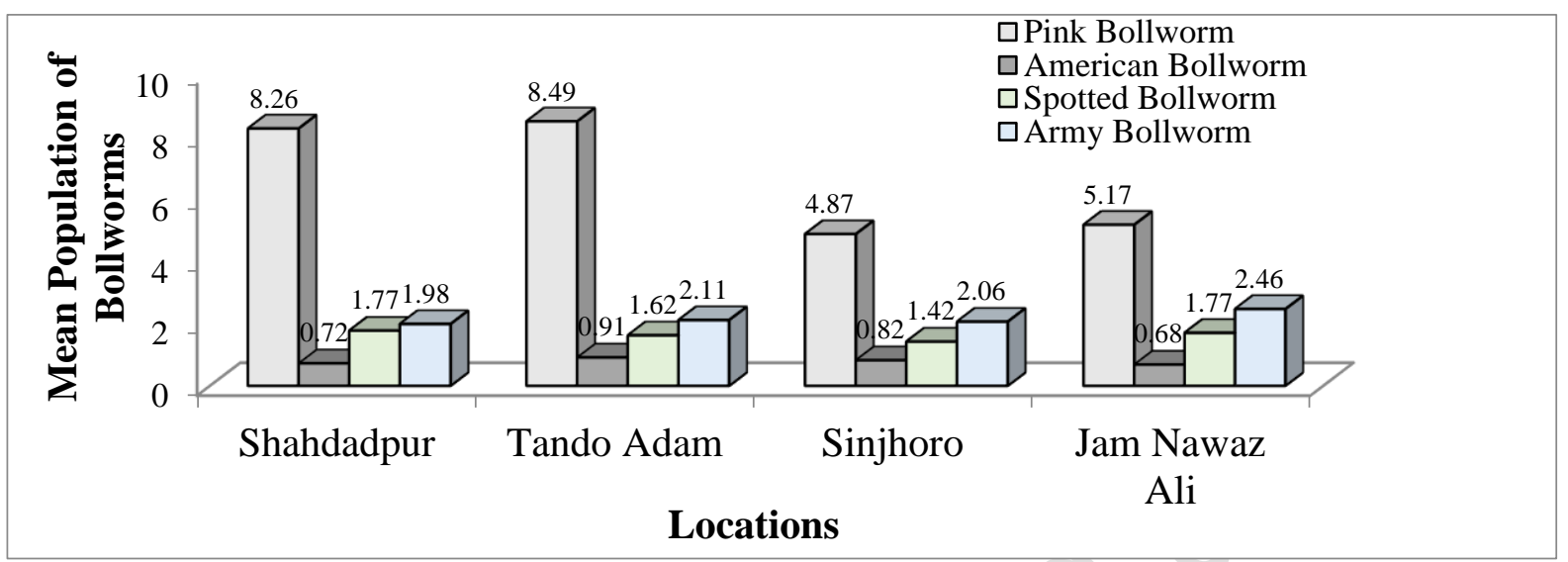

Figure 2. Mean population of cotton bollworms attracted from different locations at district Sanghar

Table 5. Correlation coefficient measured between population of bollworms and environmental factors

\begin{tabular}{|c|c|c|c|}
\hline Bollworms species & Temperature $\left({ }^{0} \mathbf{C}\right)$ & Relative Humidity (\%) & Dates (Weekly) \\
\hline Pectinophora gossypiella & $0.812^{* * \mathrm{H} . \mathrm{S}}$ & $0.69^{* \mathrm{~S}}$ & $0.52^{* \mathrm{~N} . \mathrm{S}}$ \\
\hline Earias insulana & $0.50^{* \mathrm{~S}}$ & $0.49^{* \mathrm{~S}}$ & $0.49^{* \mathrm{~N} . \mathrm{S}}$ \\
\hline Spodoptera litura & $0.63^{* * \mathrm{~S}}$ & $0.55^{* \mathrm{~S}}$ & $0.51^{* \mathrm{~N} . \mathrm{S}}$ \\
\hline Helicoverpa armigera & $0.51^{* \mathrm{~S}}$ & $0.48^{* \mathrm{~S}}$ & $0.50^{* \mathrm{~N} . \mathrm{S}}$ \\
\hline
\end{tabular}

\section{Conclusion}

On the basis of present research work on monitoring the adult population of cotton bollworms through synthetic sex pheromone traps it has been concluded that the highest population of $P$. gossypiella and $H$. armigera were found in Tandoadam, E. insulana was found in Shadadpur, and S. litura was found in Jam Nawz Ali.

\section{Authors' contributions}

Conceived and Performed the experiments: GN Sehto, IA Rajput, MM Kolachi, RAK Laghari, Designed the experiments: AM Ahmed, Provided lures: AK Pathan, Data analysis: MS Depar \& B Mal. Wrote the paper: IA Rajput.

\section{Acknowledgement}

The authors acknowledge Pakistan Agricultural Research Council and CABI Central \& West Asia International for providing facilities for the completion of this research work.

\section{References}

1. Anonymous (2002). Economic and Statistics. Int'l Cotton Advisory Committee (ICAC)
2. Hassan M (2018). Cotton output falls 25pc to $10.8 \mathrm{mln}$ bales in $2018 / 19$ - The News. www.thenews.com.pk > print > 367675cotton-output.

3. GoP (2018). Pakistan economic survey report. survey_1819

4. Ahmed M (2015). Cotton pest management in Pakistan. In Crop Prot. Int Cotton Advisory Committee, and development of spotted bollworm (Earias Spp.) on advanced genotypes of cotton under unsprayed conditions. Agric Res Pak 45(2): 145-150.

5. Malik MF, Khan AG, Hussainy SW, Rehman DU, \& Amin M (2000). Scouting and control of Helicoverpa damage, scouting and economic thresholds. Balochistan J Agric Sci 1: 44-51

6. Karim S (2000). Management of Helicoverpa armigera: A review and Prospective for Pakistan. Pak J Biol Sci 3(8): 1213-1222. 
7. Baloch AA, Kalroo AM, \& Pathan A (2000) A perspective review on Ecobiological aspects of Helicoverpa armigera by synthetic pheromones technology in apple. Asian J Pl Sci 663664.

8. Forey KE, Kittock DL, \& Heneberry TJ (2018). Effect of number of pink bollworm larvae per boll on yield and quality of Pima and Upland cotton. J Econ Entomol 71: 499-502.

9. Shah MA, Memon N, \& Balouch AA (2011). Use of sex pheromones and light Traps for monitoring of cotton bollworms in Hyderabad, Sindh, Pakistan. Sarhad J Agric 27(3): 435-442

10. Ujjan RL, Ahmed AM, Alhilfi AZA, Khoso FN, Rahoo AM, Rajput IA \& Soomro DM (2019). Performance of pheromone traps at different heights for mass trapping of Helicoverpa armigera (Noctuidae: Lepidoptera) in chickpea field. Asian J Agric Bio 7(4): 610-616

11. Gage SH, Wirth TM, \& Simmons GA (2010) Predicting regional gypsy moth (Lymantriidae) population trends in an expanding population using pheromone trap catch and spatial analysis. Env Entomol 19: 370-377.

12. El-Sayed AM, Suckling DM, Wearing H, \& Byers JA (2006). Potential of mass trapping for long-term pest management and eradication of invasive species. J Econ Entomol 99: 1550-1564

13. Gage SH, Wirth TM, \& Simmons GA (2010). Predicting regional gypsy moth (Lymantriidae) population trends in an expanding population using pheromone trap catch and spatial analysis. Env Entomol 19: 370-377

14. Baker T, Staten R \& Flint H (2010). Use of pink bollworm pheromone in the Southwestern United States. Behaviormodifying chemicals for insect management: applications of pheromones and other attractants (eds RL Ridgway, RM Silverstein \& MN Inscoe), pp 417436.

15. Gaston LK, Kaae RS, Shorey HH, \& Sellers D (2007). Controlling the pink bollworm by disrupting sex pheromone communication between adult moths. Sci (196): 904-905.

16. Chaudhari GB, Bharpoda TM, Patel JJ, Patel K \& Patel JR (1999). Effect of weather on activity of cotton bollworms in middle Gujrat. J Agro Meteor 1(2): 137138

17. Jha RC, \& Bisen RS (1994). Effect of climatic factors on the seasonal incidence of the pink bollworm on cotton crop. Ann Plant Protect Sci 2: 12-14

18. Ahmed, Z, Attique MR \& Choudhry MA (1993). The influence of slow release PVC resin pheromones formulation on the mating behavior and control of cotton bollworm complex Lepidoptera: Gellechiidae and Noctudae in Pakistan. Bull Entomolo Res 83: 335-343

19. Gaston LK, Kaee, RS, Shorey HH \& Sellers D (1977). Controlling the pink bollworm by disrupting sex pheromone communication between adult moths. Sci 196: 904-914

20. Al- Mosa H (1986). Prospects of using sex pheromone for the control of spiny bollworm in cotton growing in Syria. Dirasat (Jordan) 13: 165-174

21. Mafra-Neto A, \& Habib M (1996). Evidence that mass traping suppresses pink boll worm population in cotton fields. Entomol Exp App 81: 315-323

22. Korejo A K, Soomro AW, Mallah GH, Memon AA \& Solangi MY (2000). Monitoring Pink Bollworm seasonal population through the use of gossyplure. Pak J Biol Sci 3(12): 2119-2121

23. Asaro C, Cameron TJ, Nowak DM, Grosman JO, Seckinger A \& Berisford CW (2004). Efficacy of wing versus delta traps for predict-ing infestation levels of four generations of the Nantucket pine tip moth (Lepidoptera: Tortricidae) in the Southern United States. Environ Entomol 33: 397-404.

24. Allen DC, Abrahamson LP, Eggen DA, Lanier GN, Swier SR, \& Auger M (2016). Monitoring spruce budworm (Lepidoptera: Tortricidae) populations with pheromone-baited traps. Env Entomol 15: 152-165. 